\title{
MENINGOENCEPHALITIS DUE TO VARICELLA ZOSTER VIRUS IN AIDS PATIENTS. REPORT OF ELEVEN CASES AND REVIEW OF THE LITERATURE
}

\author{
Marcelo CORTI(1,2), María F. VILLAFAÑE(1,2), Natalia VITTAR(1), María C. BANCO(1), Maia PRIARONE(1), Lilia MAMMANA(3) \& Leonardo GILARDI(4)
}

\begin{abstract}
SUMMARY
Neurological complications of varicella-zoster virus (VZV) are infrequent and include various clinical pictures. The reactivation of VZV in patients with AIDS is generally associated with an acute and severe meningoencephalitis. We report the epidemiological, clinical and virological data from 11 consecutive patients with diagnosis of HIV/AIDS and central nervous system (CNS) involvement due to VZV. All patients were male and seropositive for HIV. The primary risk factor for HIV infection was unprotected sexual contact. The median of CD4 T cell count was 142 cells $/ \mu \mathrm{L}$. All of them presented signs and symptoms of meningoencephalitis. Six patients $(54.5 \%)$ presented pleocytosis; they all showed high CSF protein concentrations with a median of $2.1 \mathrm{~g} / \mathrm{dL}$. Polymerase chain reaction of cerebrospinal fluid specimen was positive for VZV in all of them and they were treated with intravenous acyclovir at doses of 30/ $\mathrm{mg} / \mathrm{kg} /$ day for 21 days. Overall survival was $63 \%$ (7 of 11 patients). The four dead patients had low cellular counts in CSF, below the median of this parameter. VZV should be included among the opportunistic pathogens that can involve CNS with a diffuse and severe meningoencephalitis in patients with advanced HIV/AIDS disease.
\end{abstract}

KEYWORDS: AIDS; HIV; Meningoencephalitis; Varicella-zoster virus; Polymerase chain reaction.

\section{INTRODUCTION}

Varicella-zoster virus (VZV) is a member of herpesvirus family that causes chickenpox (varicella), generally in infants, and may reactivate decades later to produce shingles (zoster). Neurological complications of VZV are rarely seen during the primary infection (varicella cerebellitis) and more often during the reactivation phase?

The most severe neurological complications occur in immunocompromised patients and include aseptic meningitis, encephalitis with vasculitis, ventriculitis, severe necrotizing myelitis, post-herpetic neuralgia, and leucoencephalopathy ${ }^{6,13}$.

We present a series of 11 AIDS patients who developed acute meningoencephalitis due to VZV.

\section{MATERIAL AND METHODS}

The epidemiological, clinical, microbiological and virological characteristics of 11 patients infected with human immunodeficiency virus (HIV), with central nervous system (CNS) involvement caused by VZV, were retrospectively analyzed from January 2002 to November 2014. We included patients hospitalized in the HIV/AIDS Department of the Infectious Diseases F.J. Muñiz Hospital with polymerase chain reaction
(PCR) positive for VZV in cerebrospinal fluid (CSF) in our Hospital's virology laboratory records. Clinical and neurological examinations were performed for all of the patients. Upon physical examination, all patients included in this study had neurological signs and/or symptoms compatible with the diagnosis of diffuse meningoencephalitis. In all of them, a lumbar puncture was performed.

White cell count was studied in all CSF samples, along with protein levels, glucose levels, common bacteria, mycobacteria, fungi, and parasites with Gram, Zielh Neelsen, Indian ink stain, and direct microscopic examination, respectively, followed by the corresponding culture methods. Further to this, neuroherpeviruses and JC virus were investigated by PCR. Blood cultures for common bacteria, fungi, and mycobacteria, and CD4+ T cell counts were also performed in all patients.

In order to define a case, we included only those patients with neurological manifestations of meningoencephalitis, positive VZV-PCR in CSF, even in the absence of clinical symptoms, and exclusion of other causes of CNS involvement in these patients.

Definitive diagnosis of VZV meningoencephalitis was made by DNA qualitative detection by PCR in CSF specimens. Aliquots of CSF samples were stored at $-70{ }^{\circ} \mathrm{C}$ until analysis. Until 2010, samples had been studied by the commercial Herpes Virus Multiplex kit (HVM-

(1) Hospital General de Infecciosas F. J. Muñiz, HIV/AIDS Division, Buenos Aires, Argentina.

(2) Universidad de Buenos Aires, Facultad de Medicina, Buenos Aires, Argentina.

(3) Hospital General de Infecciosas F. J. Muñiz, Virology Laboratory, Buenos Aires, Argentina.

(4) Sociedad Iberoamericana de Información Científica, Scientific Coordinator, Buenos Aires, Argentina.

Conflict of interest: None.

Financial funding: None.

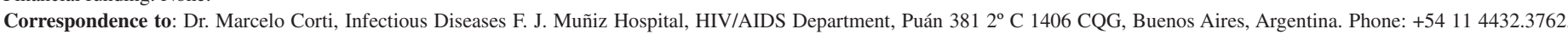

E-mail: marcelocorti@fibertel.com.ar 


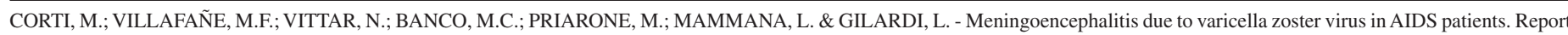
of eleven cases and review of the literature. Rev. Inst. Med. Trop. Sao Paulo. 57(6): 505-8,2015.

HERPLEX, Genomica, Spain) following the manufacturer's instructions. This is a multiplex PCR that amplifies and detects the genome of Herpes simplex-1 (HSV-1) and 2 (HSV-2) and Herpes varicella-zoster (HVZ) in a single tube as well as the cytomegalovirus (CMV) genome, EpsteinBarr virus (EBV) and human herpesvirus 6 (HHV-6). Every tube has an internal amplification control and the amplified products are detected by hybridization with specific probes in a microplate. The analytical sensitivity reported by the manufacturer is 2 genome equivalents for HSV-1, HSV-2, EBV, and between 2 and 20 genome equivalents for VZV, HHV-6 and CMV. From 2011 to 2014, the detection of DNA for all of these viruses was performed by TaqMan real time PCR (RT-PCR), using a commercially available individualized kit for each virus. The VZV Q-PCR Alert kit (Elitechgroup, Italy) was used for qualitative VZV-PCR following the manufacturer's instructions. The target amplification region of this reaction is the Major DNA binding protein from VZV (ORF 29), the internal control is the human beta globin gene and the analytical sensitivity reported is 10 DNA copies/reaction.

\section{RESULTS}

All of the patients were male and seropositive for HIV. The median age at the time ofVZV meningoencephalitis diagnosis was 37 years (mean of age $35.27 \pm 9.22$ years). Primary risk factor for HIV infection was unprotected sexual contact in all patients. Median CD4 T cell count at the time of VZV meningoencephalitis was 142 cells/ $\mu \mathrm{L}$, and a heterogeneous mean \pm SD $132 \pm 83$ cells $/ \mu \mathrm{L}$ (interquartile range [IQR]: 147.5 cells $/ \mu \mathrm{L}$ ). All patients were diagnosed with AIDS based on the clinical history of AIDS defining illnesses or the CD4 T cell count below 200 cells $/ \mu \mathrm{L}$. At the time of VZV meningoencephalitis there was no evidence of other neurological opportunistic infections or AIDS-defining illnesses. Due to their own decision, none of the patients had received antiretroviral therapy. Main results are summarized in Table 1.

Clinical examination revealed headache in eight patients $(72 \%)$; fever in seven patients (63\%); meningism in four patients (36\%); focal neurological signs in four (36\%); sensory impairment in three $(27 \%)$; vomiting in three patients $(27 \%)$ and seizures in one (9\%). Only one patient $(9 \%$ ) had no signs or symptoms of neurological involvement and, in this case, the identification of VZV in CSF was an incidental finding. Eight patients $(72 \%)$ presented concomitant mucocutaneous lesions, compatible with VZV eruptions. Median of CSF glucose was $51 \mathrm{mg} /$ dL (range: $30-114 \mathrm{mg} / \mathrm{dL}$ ) and median of cellularity was 57 cells $/ \mathrm{mL}$ (range $1-950$ cells $/ \mathrm{mL}$ ); six patients $(54.5 \%)$ presented pleocytosis. All patients showed high CSF protein concentration with a median of $2.1 \mathrm{~g} /$ dL (range: 0.65-3.45 g/dL). In all cases, PCR was positive for VZV and negative for HSV-1, HSV-2, HHV-6, EBV and CMV, either by MHV or RT-PCR. Main results are summarized in Table 2.

All of the patients were treated with intravenous acyclovir at doses of 30/mg/kg/day for 21 days. Overall survival rate was $63 \%$ (seven of 11 patients). The four dead patients had low cellular count in CSF, below the median of this parameter (median: 3 cells/ $\mu \mathrm{L}$, IHQ: 7.5 cells $/ \mu \mathrm{L}$ ), but the clinical presentation did not differ from the entire cohort.

\section{DISCUSSION}

Reactivation of VZV infection in the CNS is more common in patients with AIDS in comparison with other immunodeficient patients and immunocompetent individuals. This population accounts for $2 \%$ of the cases with neurological involvement. GRAY et al. (1994) reported VZV reactivation in CNS in more than $4 \%$ of AIDS patients. Meningoencephalitis is more frequent than myelitis ${ }^{6,11}$. The pathogenic mechanisms of VZV reactivation in the CNS include neuronal and glial direct infection and immune mediated lesions including vasculitis and demyelization ${ }^{7}$.

Clinical manifestations include diffuse meningoencephalitis, focal encephalitis and meningoencephalomyelitis. VZV myelitis, as the only manifestation of the disease, is rare and occurs in less than $1 / 1000$ cases $^{2}$.

In the HIV population, VZV reactivation in the CNS is associated with a low CD4+ $\mathrm{T}$ cell count and, in the majority of the patients,

Table 1

Main basal characteristics of the study group.

\begin{tabular}{lccccc}
\hline$\#$ & Age (years) & T-HIV-D (years) & CD4 $(/ \mu \mathrm{L})$ & Prior ND & Prior non ND \\
\hline 1 & 25 & 16 & N/A & N/A & N/A \\
2 & 39 & 15 & N/A & None & Syphilis \\
3 & 24 & 10 & 233 & None & Gut tuberculosis \\
4 & 53 & 1 & 83 & None & Hepatitis B \\
5 & 46 & 12 & 223 & Toxoplasmosis & N/A \\
6 & 26 & 3 & None & Pulmonary tuberculosis $\left(^{*}\right)$ \\
7 & 40 & 13 & 142 & Toxoplasmosis & Disseminated histoplasmosis $(*)$ \\
8 & 30 & 2 & 189 & Ophthalmic zoster & Non Hodgkin lymphoma \\
9 & 30 & N/A & N/A & N/A & N/A \\
10 & 38 & 7 & N/A & N/A & N/A \\
11 & 37 & N/A & 34 & N/A &
\end{tabular}

T-HIV-D: time from HIV diagnosis to VZV meningoencephalitis diagnosis. N/A: not available. ND: neurological diseases. (*) among others. 
CORTI, M.; VILLAFAÑE, M.F.; VITTAR, N.; BANCO, M.C.; PRIARONE, M.; MAMMANA, L. \& GILARDI, L. - Meningoencephalitis due to varicella zoster virus in AIDS patients. Report of eleven cases and review of the literature. Rev. Inst. Med. Trop. Sao Paulo. 57(6): 505-8,2015.

Table 2

Main clinical characteristics

\begin{tabular}{|c|c|c|c|c|c|c|c|c|}
\hline \# & Meningism & Seizures & Headache & Fever & $\begin{array}{c}\text { Concomitant } \\
\text { mucocutaneous lesions }\end{array}$ & $\begin{array}{c}\text { Focal } \\
\text { neurological signs }\end{array}$ & PCR-VZV-CSF & Outcome \\
\hline 1 & Absent & Absent & Present & Present & Present & Absent & Positive & Survival \\
\hline 2 & Present & Absent & Present & Present & Present & Present & Positive & Survival \\
\hline 3 & Absent & Absent & Present & Absent & Present & Absent & Positive & Death \\
\hline 4 & Absent & Absent & Present & Present & Present & Absent & Positive & Survival \\
\hline 5 & Absent & Present & Absent & Present & Absent & Absent & Positive & Survival \\
\hline 6 & Present & Absent & Present & Present & Absent & Absent & Positive & Death \\
\hline 7 & Present & Absent & Present & Absent & Present & Absent & Positive & Survival \\
\hline 8 & Absent & Absent & Absent & Absent & Present & Present & Positive & Survival \\
\hline 9 & Absent & Absent & Present & Absent & Absent & Present & Positive & Survival \\
\hline 10 & Present & Absent & Absent & Present & Present & Present & Positive & Death \\
\hline 11 & Absent & Absent & Present & Present & Present & Absent & Positive & Death \\
\hline
\end{tabular}

PCR-VZV-CSF: cerebrospinal fluid polymerase chain reaction for varicella zoster virus.

mucocutaneous lesions precede CNS involvement. In addition, some patients present early neurological manifestations of meningoencephalitis before maculovesicular exanthema appear while others have late complications such as vasculitis with granulomatous angeitis 9 . Nevertheless, detection of VZV in CSF is possible in the absence of rash. In our series, we could detect mucocutaneous eruptions with foamy virus in Tzanck cytodiagnosis compatible with VZV in eight of the 11 patients (72\%). The most common clinical picture in our series was the meningeal signs (36\%) associated with fever $(63 \%)$ and headache $(72 \%)$.

Diagnosis of VZV meningoencephalitis includes neurological manifestations, a positive CSF result for VZV DNA, and the absence of any other identifiable pathogen in CSF. All of the patients described in this report, excepting for one case, presented these three clinical and laboratory findings.

Since its introduction in 1990, the PCR technique has contributed to the diagnosis of neurological infections caused by herpesvirus. This very sensitive and specific technique has overwhelmed the serological diagnosis of neuroherpeviruses infections in $\mathrm{CSF}^{1}$. Amplification of VZV DNA in CSF by PCR is the gold standard method in diagnosis of the clinical spectrum of neurological disorders associated with herpesvirus ${ }^{2,10}$. When the CSF sample is taken within the first few days after the onset of neurological symptoms, the rate of PCR positive is higher than afterwards ${ }^{1,3}$. The overall sensitivity is approximately $90 \%$ with a specificity of $100 \%{ }^{12}$.

Another interesting issue that concerns the viral load evaluation in the analysis of CSF samples is the future incorporation of the quantitative VZV RT-PCR, which is being applied more and more ${ }^{4}$.

Information on VZV meningoencephalitis series in HIV-infected patients is still limited. To date, very few cases of VZV meningoencephalitis in HIV-infected patients have been published. In a large series of 514 consecutive HIV infected patients with neurological disorders, VZV
DNA was found in CSF samples of $2.5 \%$ of the cases (13 patients). Only four of these 13 patients had the diagnosis of VZV meningoencephalitis or encephalomyelitis ${ }^{1,5}$. To the best of our knowledge, this is the larger series of CNS reactivation of VZV in HIV/AIDS patients.

In conclusion, reactivation of VZV in CNS is a severe and lifethreatening complication in HIV/AIDS patients. Infectologists should consider the presence of VZV DNA in CSF concomitantly with other viruses, or simultaneously with the occurrence of HIV neurological complications, either in the presence or absence of mucocutaneous lesions of VZV.

\section{RESUMO}

\section{Meningoencefalite pelo vírus varicela-zoster em pacientes com AIDS. Relato de onze casos e revisão da literatura}

As complicações neurológicas do vírus varicela-zoster (VVZ) são pouco frequentes e incluem vários quadros clínicos. A reativação do VVZ em pacientes com AIDS é geralmente associada com meningoencefalite aguda e grave. Nós relatamos os dados epidemiológicos, clínicos e virológicos de onze pacientes consecutivos com diagnóstico de HIV/ AIDS e comprometimento do sistema nervoso central (SNC) devido ao VVZ. Todos os pacientes eram do sexo masculino e soropositivos para HIV. O principal fator de risco para a infecção pelo HIV foi o contato sexual sem proteção. A mediana da contagem de células CD4 T foi de 142 $\mathrm{cel} / \mu \mathrm{L}$. Todos apresentavam sinais e sintomas devido à meningoencefalite. Seis pacientes $(54,5 \%)$ apresentaram pleiocitose; todos apresentaram hiperproteinorraquia com mediana de $2,1 \mathrm{~g} / \mathrm{dL}$. A reação em cadeia da polimerase de amostra do líquido cefalorraquidiano foi positiva para VVZ em todos eles. Todos os pacientes foram tratados com aciclovir por via intravenosa em doses de $30 \mathrm{mg} / \mathrm{kg} /$ dia durante 21 dias. A sobrevida global foi de $63 \%$ (sete de 11 pacientes). Os quatro pacientes mortos tiveram uma escassa resposta celular no LCR abaixo da mediana para este parâmetro. OVVZ deve ser incluído entre os patógenos oportunistas 
CORTI, M.; VILLAFAÑE, M.F.; VITTAR, N.; BANCO, M.C.; PRIARONE, M.; MAMMANA, L. \& GILARDI, L. - Meningoencephalitis due to varicella zoster virus in AIDS patients. Report of eleven cases and review of the literature. Rev. Inst. Med. Trop. Sao Paulo. 57(6): 505-8,2015.

que podem comprometer o SNC com meningoencefalite difusa e grave em pacientes com doença avançada por HIV/SIDA.

\section{REFERENCES}

1. Cinque P, Vago L, Dahl H, Brytting M, Terreni MR, Fornara C, et al. Polymerase chain reaction on cerebrospinal fluid for diagnosis of virus associated opportunistic diseases of the central nervous system in HIV-infected patients. AIDS. 1996;10:951-8.

2. Corti M, Trione N, Villafañe MF, Risso D, Yampolsky C, Mamanna L. Acute meningoencephalomyelitis due to Varicella-Zoster virus in an AIDS patient: report of a case and review of the literature. Rev Soc Bras Med Trop. 2011;44:784-6.

3. Corti M, Villafañe MF, Trione N, Mamanna L, Bouzas B. Human herpesvirus 6: report of emerging pathogen in five patients with HIV/AIDS and review of the literature. Rev Soc Bras Med Trop. 2011;44:522-5.

4. Gaeta A, Verzaro S, Latte MC, Mancini C, Nazzari C. Diagnosis of neurological herpesvirus infections: real time PCR in cerebral spinal fluid analysis. New Microbiol. 2009;32:333-40.

5. Gilden DH, Beinlich BR, Rubisntein EM, Stommel E, Swenson R, Rubisntein D, et al. Varicella-zoster virus myelitis: an expanding spectrum. Neurology. 1994;44:1818-23.

6. Gilden DH, Kleinschmidt-DeMasters BK, La Guardia JJ, Mahalingam R, Cohrs R. Neurologic complications of the reactivation of varicella-zoster virus. N Engl J Med. 2000;342:635-45
7. Glesby MJ, Moore RD, Chaisson RE. Clinical spectrum of herpes zoster in adults infected with human immunodeficiency virus. Clin Infect Dis. 1995;21:370-5.

8. Gray F, Bélec L, Lescs MC, Chrétien F, Ciardi A, Hassine D, et al. Varicella-Zoster virus infection of the central nervous system in the acquired immune deficiency syndrome. Brain. 1994;117:987-99.

9. Martín del Pozo M, Benito-León J, Rodríguez J, Molina JA, Díaz-Guzmán J, Bermejo FP. Uncommon neurologic complications related with varicela-zoster virus. Neurología. 1998;13:94-7.

10. Mayo DR, Booss J. Varicella zoster associated neurologic disease without skin lesions. Arch Neurol. 1989;46:313-5.

11. Morgello S, Block GA, Price RW, Petito CK. Varicella-zoster virus leukoencephalitis and cerebral vasculopathy. Arch Pathol Lab Med. 1988;112:173-7.

12. Puchhammer-Stöckl E, Popow-Kraupp T, Heinz FX, Mandl CW, Kunz C. Detection of varicella-zoster virus DNA by polymerase chain reaction in cerebrospinal fluid of patients suffering neurological complications associated with chicken pox or herpes zoster. J Clin Microbiol. 1991;29:1513-6.

13. Toledo PV, Pellegrino LN, Cunha CA. Varicella-zoster virus encephalitis in an AIDS patient. Braz J Infect Dis. 2004;8:255-8.

Received: 05 January 2015

Accepted: 02 April 2015 